\title{
Assessment of economic and environmental performance in citrus-based intercropping systems
}

\author{
Carlos Roberto Martins ${ }^{1}$, Geraldo Stachetti Rodrigues ${ }^{2}$, Inácio de Barros ${ }^{3}$
}

\begin{abstract}
The economic and environmental performances of agriculture intercropping depend on the complementarities between the crops that make up the system. The objective of this work was to analyze the citrus-based intercropping systems in the Coastal Tablelands region of Northeastern Brazil, aiming to identify the associations of crops with better economic and environmental performances. The study started with the construction of a set of integrated indicators, with which the field information was recorded and the performance indices calculated, based on three principles: Profitability, Productive Efficiency, and Biological Regulation. Citrus orchards in monoculture resulted in lower environmental economic performance indices. The intercropping systems that yielded the best environmental and economic performance indices in the citrus orchards were: cassava; cassava, corn and beans; corn and pumpkin. The indicators associated with these economicenvironmental performances were profit, seasonality, productive diversity, profit evenness, plant health control impact level, and efficiency in the use of water, nitrogen, and phosphate.
\end{abstract}

Index terms: fruticulture, citriculture, sustainability assessment, Coastal Tablelands, smallholding growers

\section{Avaliação de desempenho econômico e ambiental de sistemas consorciados à base de citros}

Corresponding author: carlos.r.martins@embrapa.br

Received: July 06, 2019 Accepted: October 01, 2020

Copyright: All the contents of this journal, except where otherwise noted, is licensed under a Creative Commons Attribution License.

\section{(cc) $\mathbf{E Y}$}

Resumo - O desempenho econômico e ambiental do consórcio agrícola depende das complementaridades entre as culturas que compõem o sistema. O objetivo deste trabalho foi analisar os sistemas de consorciação à base de citros na região dos Tabuleiros Costeiros do Nordeste do Brasil, visando a identificar as consorciações de culturas com melhores desempenhos econômico e ambiental. O estudo iniciou-se com a construção de um conjunto de indicadores integrados, com os quais foram registradas as informações de campo e calculados os índices de desempenho, com base em três princípios: Rentabilidade, Eficiência Produtiva e Regulação Biológica. Os pomares de citros em monocultivo resultaram em menores índices de desempenho econômico ambiental. As combinações de cultivos consorciados aos citros que promoveram os melhores índices de desempenho econômico ambiental foram: mandioca; mandioca, milho e feijão; milho e abóbora. Os principais indicadores associados a este desempenho econômico ambiental foram o nível de impacto do controle fitossanitário, a diversidade produtiva, a lucratividade do consórcio, o equilíbrio da rentabilidade, o retorno do investimento em energia fóssil, e a eficiência do uso de água, de nitrogênio e de fósforo.

Termos para indexação: fruticultura, citricultura, avaliação da sustentabilidade, planaltos costeiros, pequenos agricultores.

\footnotetext{
${ }^{1}$ Agronomist, Dr., Researcher, Embrapa Clima Temperado (EMBRAPA), Pelotas, Rio Grande do Sul State, Brazil. E-mail:carlos.r.martins@ embrapa.br (ORCID 0000-0001-8833-1629)

${ }^{2}$ Ecologist, Dr., Researcher, Embrapa Meio Ambiente (EMBRAPA), Jaguariúna, São Paulo State, Brazil. E-mail: geraldo.stachetti@embrapa.br ${ }^{\text {(ORCID }}$ 0000-0002-5604-3531)

${ }^{3}$ Agronomist, Dr., Researcher, Embrapa Gado de Leite (EMBRAPA), Juiz de Fora, Minas Gerais State, Brazil. E-mail: inacio.barros@embrapa.br (ORCID 0000-0002-0185-7984)
} 


\section{Introduction}

Citrus fruits are among the most consumed in the world, either in the form of fresh fruit or juice. In Brazil, 18 million tons of oranges are harvested annually, representing $35 \%$ of global fruit production and $56 \%$ of the world's orange juice (CURTOLO et al., 2017), accounting for approximately $73 \%$ of the international market (FAS-USDA, 2019). The Northeast region of the country accounts for approximately $10 \%$ of the national citrus production, making it the second largest producing region after the Brazilian citrus belt in the Southeast (NEVES et al., 2011). With 142,826 hectares of orchards and producing 1,948,043 tons of fruits, with an average yield of approximately 13.3 tha $^{-1}$ (IBGE, 2018), the region stands as the seventh largest orange producer in the world.

In striking contrast with the intensive monoculture plantations of the main producing regions in the country's Southeast, the citrus orchards of Northeastern Brazil are usually grown amid coconut plantations, seasonal maize crops and extensive pastures along the zone known as Coastal Tablelands (CARVALHO et al., 2020; MELO FILHO et al., 2009). The orchards are planted mostly with orange cv. Pera (Citrus sinensis [L.] Osbeck) (CARVALHO et al., 2020; RODRIGUES et al., 2016; TEODORO, 2020) grafted on Rangpur lime (C. limonia Osbeck) (MARTINS et al. 2016; MENESES et al., 2019; CARVALHO et al., 2019; SANTANA et al. 2019), either as monocultures with production mostly directed to the juice processing industry, or as multi-species intercropping systems directed to the local fruit markets.

Such multi-species inter-cropping systems have been used as an alternative to traditional farming systems, with the potential to increase land productivity and diversify production (OUMA; JERUTO, 2010; DAI et al., 2017; PAUT et al., 2020; ROSA-SCHLEICH et al., 2019), and favors greater biological balance, reducing problems with pests, diseases and weeds in the orchards, hence reducing the dependence on external inputs (DURU et al., 2015; BELLOTE et al., 2013; GABA et al., 2015) while increasing farmers' income (DAI et al., 2017).

Citrus intercropping systems have been studied in several countries, involving a diversity of forest species (COELHO, 2017; HARRISON AND HARRISON, 2016; MVONDO et al., 2019; PAULUS et al., 2019) and other fruit trees (OUMA AND JERUTO, 2010; ANDOMENSAH AND OFOSU-BUDU, 2012; SINGHA et al., 2018; GILL et al., 2018), as well as intercropping with vegetables (SINGH et al., 2018), cover crops and grain plants (MARTINELLI et al., 2017; MULINGE et al., 2018), grasses (BELLOTE et al., 2013) and legumes (SELIM et al., 2020; LINARES et al., 2008; DAI et al., 2019). Although very valuable for providing management recommendations for these alternative cropping systems, these studies do not offer critical assessments of the differential performances of those varied crop associations, as compared to conventional monocrop citrus orchards; or quantitative bases for explaining and ranking the economic and environmental performances of those alternatives, as to facilitating technical decision on intercropping options and selection of appropriate indicators for such decisions.

Intercropping favors the conservation of agroecosystem functions which are compatible with the premises of sustainable intensification of agriculture (BARROS et al., 2016; GRIFFON, 2013). The main interests in studying the interactions of agricultural processes in multi-species systems, in which production is maintained or increased, with maximization of biodiversity functionalities, include avoiding the expansion of cultivated areas, thus preventing greater losses of natural habitats (KLEIJN et al., 2019). These valuable sustainability objectives, such as increased yields and resilient agricultural systems, can be effectively achieved by redesigning cropping systems (PRETTY, 2018).

On its turn, the economic and environmental performances of multi-species intercropping with fruit trees depend on both, the agronomic and the market complementarities of the combined crops (OUMA AND JERUTO, 2010). Lack of management information and knowledge about citrus intercropping may result in low yields and short shelf-life of the main crop. Thus, the most appropriate multi-species combinations should be identified, in view of the complementary and supplementary relationships between citrus and intercropping species (GILL et al., 2018).

In this context, the objective of this study is twofold: (1) to propose a set of integrated indicators for the assessment of the economic and environmental performances of citrus-based intercropping systems and (2) to present the results obtained in the field application of the proposed indicators system, corresponding to a group of reference citrus production farms in the Coastal Tablelands region in Brazil.

\section{Material and methods}

The present study was carried out in citrus farms in the Coastal Tablelands Landscape Unit of Southern Sergipe and Northern Bahia states, Brazil, encompassing the municipalities and involving the production areas shown in Table 1. The sampling plan strived to encompass a representation of $80 \%$ of citrus producers in the region, whose individual farms reach an area of less than 10 ha (MARTINS et al., 2020). In addition, it sought to include the main multi-species intercropping systems employed in the region, mostly characterized by short cycle secondary crops. 
The main soils in this landscape unit are Yellow Ferralsols and Dystrophic yellow Acrisols (WRB/FAO), prone to exhibiting a marked hardsetting layer $(<150 \mathrm{~cm}$ deep), acidic, Halic, with low cation exchange capacity (GOMES et al., 2017). The climate is $A s^{\prime}$ type in the Köppen-Geiger classification, i.e., tropical rainy with dry summer, with mean annual precipitation of $1,317 \mathrm{~mm}$ (CARVALHO et al., 2019).

The field studies were carried out from July 2014 to October 2015, in 19 fruit farms whose main crop is citrus, with cropping combinations as presented in Table 2 .

A system of economic and environmental performance indicators was built following the approach used by Rodrigues et al. (2009) for formulating the 'Traditional Agroforestry Performance Indicators System' (TAPIS). Aiming at improving farmers' management capacity (essentially a biophysical efficiency attribute) and fostering sustainability of landholdings (essentially a socioeconomic adequacy attribute), a set of appropriate field measurements was listed and selected to produce coherent indicators, as advocated by several authors (BOCKSTALLER et al. 1997; BOSSHARD, 2000; GIRARDIN et al. 1999; LEWANDOWSKI et al. 1999; RODRIGUES et al., 2010).

These aforementioned objectives provided the basis for grading all selected field measurement variables according to improved or worsened performances, allowing the ranking of reference farms into normalized and aggregated indicators, as suggested by Andreoli and Tellarini (2000). This methodological approach aimed at providing farmers with useful information, regarding the economic and environmental performances of the corresponding crop combinations they used. The advantage of opting for normalization of data sets and indicators (instead of, for example, utility valuation or benchmarking) is the consistency obtained for the ranking baseline, and the meaning of the information conveyed by the indicators pertaining to the local reality (HARDI AND DESOUZA-HULETEY, 2000).

Three main principles guided the plot performance ranking: profitability, production efficiency and biological regulation, and these principles were expressed through twelve indicators as follow:

I) Profitability - represented by the indicators:

\section{1. $\quad$ Profit $(P r)$ :}

$\operatorname{Pr}=\frac{\text { (value citrus }+ \text { intercrop species })-(\text { costs citrus }+ \text { intercrop species })}{\text { (value citrus }+ \text { intercrop species })}$

2. Profit evenness $(P E)$ :

$$
P E=50-\left|50-\left[\frac{\text { value intercrop species }}{\text { (value citrus }+ \text { intercrop species })}\right] * 100\right|
$$

3. Income seasonality $(S)$ :

$$
S=1-G
$$

Where: $G$ is the Gini coefficient for income distribution (citrus plus intercrop species) along the year (monthly basis).

II) Production efficiency - represented by the indicators:

4. Area Equivalent Index $(A E I)$ :

$A E I=\sum_{i=1}^{n} \frac{\text { number of plants of the specie " } i \text { " in the intercrop }}{\text { stand number of plants for species " } i \text { " in monocrop }}$

5. Efficiency in the use of water $(E W)$ :

$E W=\frac{\text { Exported biomass }}{(\text { mm irrigation }+ \text { mm precipitation })}$

6. Efficiency in the use of $\mathrm{N}(E N)$ :

$$
E N=\frac{\text { Exported } N}{\text { Applied } N}
$$

7. Efficiency in the use of $\mathrm{P}(E P)$ :

$$
E P=\frac{\text { Exported } P}{\text { Applied } P}
$$

8. Efficiency in the use of $\mathrm{K}(E K)$ :

$$
E K=\frac{\text { Exported } K}{\text { Applied } K}
$$

9. Return on investment in fossil fuel energy

(RIFFE):

$$
\text { RIFFE }=\frac{\text { Exported energy }}{\text { Fossil energy used }}
$$

10. Return on investment in labor $(R I L)$ :

$$
R I L=\frac{\text { Exported energy }}{\text { men }- \text { days used }}
$$

III) Biological regulation - represented by the indicators:

11. Plant health control impact level (PHCIL):

$$
\text { PHCIL }=\sum_{i=1}^{5}(\text { Interventions })_{i} *(\text { Toxicity Factor })_{i}
$$

Where: 
(Interventions) $)_{i}$ is the number of phytosanitary interventions (for insect, disease and weed control) of toxicological class " $i$ ";

(Toxicity Factor) ${ }_{i}$ is the weighting factor associated to interventions of toxicological class " $i$ " being:

$i=1$ for manual/mechanical or biological intervention and (Toxicity factor) $)_{1}=0.10$;

$i=2$ for interventions with Less toxic chemical products (Green: oral LD50 $>500 \mathrm{mg} . \mathrm{kg}^{-1}$ live weight) and (Toxicity factor $)_{2}=0.25$;

$i=3$ for interventions with Moderately toxic chemical products (Blue: $50 \mathrm{mg} \cdot \mathrm{kg}^{-1}<$ oral LD50 $<500$ mg.kg-1 live weight) and (Toxicity factor) ${ }_{3}=0.33$;

$i=4$ for interventions with Highly toxic chemical products (Yellow: $5 \mathrm{mg} \cdot \mathrm{kg}^{-1}<$ oral LD50 $<50 \mathrm{mg} \cdot \mathrm{kg}^{-1}$ live weight) and (Toxicity factor) ${ }_{4}=0.50$;

$i=5$ for interventions with Extremely toxic chemical products (Red: oral LD50 $<5 \mathrm{mg} \cdot \mathrm{kg}^{-1}$ live weight) and (Toxicity factor $)_{5}=1.00$;

12. Productive diversity $(P D)$ :

$$
P D=-\sum_{j=1}^{n} p_{j} * \ln p_{j} ;
$$

Where:

$$
p_{j}=\frac{\text { Biomass produced by crop " } j " \text { (including citrus) }}{\text { Total biomass produced by all crops (including citrus) }}
$$

Reference data and default values for all required coefficients in the above equations, for computation of each indicator, were assembled in a template spreadsheet, for automatic calculation and graphic expression of all estimations. This template spreadsheet (named 'Indicator system for performance evaluation of citrus intercropping') was formulated as to accommodate all field information for the 19 reference farms in the study, as well as new case studies that may be inserted in the database, facilitating the extension of the sample. The required default values and equation coefficients, for the variables in each crop, and respective source database or specific reference are shown in Table 3.
The field results of case studies carried out in the citrus orchards are presented in the 'Indicator system for performance evaluation of citrus intercropping' in graphs for each principle considered, allowing the verification of performance for the intercrop area in each indicator in a scale of zero to 1 (the closer to 1 the better the performance), normalized for the series of case studies included in the template, favoring the selection of management practices to maximize performance, according to farmer's objectives. An aggregated environmental-economic performance index was also calculated as the average of the 12 indicators assessed for each studied reference farm.

A Principal Component Analysis (PCA) was also performed in order to identify the multiple correlations between all indicators and the distribution of the reference farms in the plane of the first two principal components. The results of the PCA are presented as a biplot showing the correlation circle of the indicators and the observation clouds (reference farms) in the plane of two most important principal components.

\section{Results and discussion}

The mean environmental-economic performance indices observed in the rural establishments studied, as defined by the 12 indicators assessed, ranged from 0.19 to 0.63 , with an average of 0.45 . Figure 1 shows the integrated environmental-economic performances of citrus production, both in monoculture (reference farms 1 and 2) and in multi-species intercropping areas, in the 19 case studies carried out in the region, and the individual results (normalized $0-1$ ) of each indicator for all 19 farms are presented in Table 4. 
Table 1. Sampling localities, case designation and cultivated areas of the 19 rural establishments included in the study, in the Coastal Tablelands Landscape Unit of Southern Sergipe and Northern Bahia states, Brazil.

\begin{tabular}{cllc}
\hline Reference case of studied farm & State & Municipality & Orchard area (ha) \\
\hline 1 & Sergipe & Itabaininha & 15 \\
2 & Sergipe & Boquim & 7,4 \\
3 & Bahia & Rio Real & 9,1 \\
4 & Sergipe & Santa Luzia do Itanhy & 7,3 \\
6 & Sergipe & Arauá & 3,8 \\
7 & Sergipe & Lagarto & 9,0 \\
8 & Sergipe & Tomar do Geru & 4,2 \\
9 & Sergipe & Salgado & 3,0 \\
10 & Sergipe & Pedrinhas & 2,8 \\
11 & Sergipe & Arauá & 2,4 \\
12 & Sergipe & Cristinópolis & 9,2 \\
13 & Sergipe & Estância & 5,6 \\
14 & Sergipe & Umbauba & 4,0 \\
15 & Bahia & Acajutiba & 2,1 \\
16 & Sergipe & Riachão das Dantas & 4,6 \\
17 & Sergipe & Indiaroba & 3,5 \\
18 & Bahia & Esplanada & 2,9 \\
19 & Bahia & Itapicuru & 1,2 \\
& Bahia & Jandaia & 3,2 \\
\hline
\end{tabular}

Source: Autors

Table 2. Reference farms and intercropping systems studied.

\begin{tabular}{cccc}
\hline $\begin{array}{c}\text { Reference } \\
\text { Farm }\end{array}$ & Intercrop species 1 & Intercrop species 2 & Intercrop species 3 \\
\hline 1 & - & - & - \\
2 & - & - & - \\
3 & Papaya (Carica papaya) & Watermelon (Citrullus lanatus) & Peanuts(Arachis hypogaea) \\
4 & Cassava (Manihot esculenta) & Papaya & - \\
5 & Cassava & - & Cassava \\
6 & Corn (Zea mays) & Cowpea Vigna unguiculata) & - \\
7 & Fava (Vicia faba) & Corn & - \\
8 & Cassava & - & - \\
9 & Pumpkin (Curcubita spp) & Corn & - \\
10 & Okra (Abelmoschus esculentus) & Yam (Dioscorea sp) & - \\
11 & Papaya & Passion fruit (Passiflora edulis) & - \\
12 & Cowpea & Pumpkin & - \\
13 & Corn & - & - \\
14 & Peanuts & - & - \\
15 & Cassava & Corn & - \\
16 & Passion Fruit & - & - \\
17 & Okra & Pumpkin & - \\
18 & Common beans (Phaseolus vulgaris) & - & Corn \\
19 & Passion fruit & & \\
\hline
\end{tabular}


Table 3. Required coefficients, default values and information sources for the 'Indicator system for performance evaluation of citrus intercropping'.

\section{Elemental contents}

\begin{tabular}{|c|c|c|c|c|c|c|c|}
\hline $\begin{array}{c}\text { Associated } \\
\text { crop }\end{array}$ & $\begin{array}{c}\text { (a) } \\
\text { Standard stand } \\
\text { (number of } \\
\text { plants/ha) } \\
\text { when sole crop }\end{array}$ & $\begin{array}{c}\text { (b) } \\
\text { Nitrogen } \\
\text { (mg/g FW) }\end{array}$ & $\begin{array}{c}\text { (c) } \\
\text { Phosphorus } \\
\text { (ppm FW) }\end{array}$ & $\begin{array}{c}\text { (d) } \\
\text { Potassium } \\
(\mathrm{mg} / \mathrm{g} \text { FW) }\end{array}$ & $\begin{array}{c}(\mathrm{e}) \\
\text { Fresh Energy } \\
\text { content } \\
(\mathbf{M J} / \mathbf{k g ~ F W )}\end{array}$ & $\begin{array}{c}\text { (f) } \\
\text { Dry matter } \\
\text { (\% decimal) }\end{array}$ & $\begin{array}{c}\text { Energy } \\
\text { (MJ/kg MS) }\end{array}$ \\
\hline Citrus & $416^{(\mathrm{a} 1)}$ & 1.773 & 221 & 2.6 & 2.9 & 0.158 & 18.1 \\
\hline Cassava & $16000^{(\mathrm{a} 2)}$ & 1.378 & 220 & 3.6 & 1.98 & 0.118 & 16.8 \\
\hline Corn & $60000^{(a 3)}$ & 1.232 & 2450 & 5.0 & 16.7 & 0.875 & 19.1 \\
\hline Peanut & 50000 & 4.533 & 4388 & 6.8 & 28.0 & 0.954 & 29.3 \\
\hline Cowpea & $60000^{(\mathrm{a} 4)}$ & 3.578 & 3592 & 13.5 & 16.7 & 0.898 & 18.6 \\
\hline Yam & $20800^{\text {(a5) }}$ & 0.165 & 1224 & 4.9 & 2.9 & 0.166 & 17.3 \\
\hline Common bean & $200000^{\text {(a6) }}$ & 3.535 & 4366 & 15.1 & 16.6 & 0.891 & 18.6 \\
\hline Pumpkin & $660^{(\mathrm{a} 7)}$ & 0.176 & 198 & 3.4 & 1.4 & 0.076 & 17.8 \\
\hline Watermelon & $400^{(\mathrm{a} 8)}$ & 0.126 & 229 & 2.7 & 1.5 & 0.079 & 19.5 \\
\hline Papaya & $1330^{(\mathrm{a} 9)}$ & 0.148 & 131 & 1.8 & 1.4 & 0.082 & 17.1 \\
\hline Passionfruit & $2220^{(\mathrm{a} 10)}$ & 3.520 & 680 & 3.5 & 4.1 & 0.082 & 49.5 \\
\hline Okra & 40000 & 0.396 & 72 & 0.37 & 1.4 & 0.12 & 11.2 \\
\hline Fava bean & 20000 & 4.041 & 269 & 1.57 & 16.7 & 0.898 & 18.6 \\
\hline
\end{tabular}

Coefficients' information sources: (a1) AZEVEDO, C. L. L.; PASSOS, O. S.; SANTANA, M. A. Sistema de produção para pequenos produtores de citros do Nordeste. Cruz das Almas: Embrapa Mandioca e Fruticultura, 2006. 55p. (Embrapa Mandioca e Fruticultura. Documentos, 157). (a2) Wichmann, W. World Fertilizer Use Manual, Publisher: BASF AG, Germany, IFA, France, 1992.

(a3) CRUZ, J.C. (Ed.). Cultivo do milho. 6.ed. Sete Lagoas: Embrapa Milho e Sorgo, 2010. (Embrapa Milho e Sorgo. Sistema de produção. (a4) RIBEIRO VQ. Cultivo do feijão-caupi (Vigna unguiculata (L.) Walp.). Teresina: Embrapa Meio-Norte, 2002. 108p. (Embrapa Meio-Norte. Sistemas de Produção: 2)

(a5) Vidal C.R.M. Absorção de NPK na cultura do inhame (Dioscorea cayennensis Lam) em três densidades de plantio. Universidade Federal do Recôncavo da Bahia, 2008.

(a6) ABREU, Â. de F. B.; BIAVA, M. (Ed.). Cultivo do feijão da primeira e segunda safras na Região Sul de Minas Gerais. Embrapa Arroz e Feijão;(Embrapa Arroz e Feijão. Sistemas de produção, 6).

(a7) RAMOS, S.R.R. et al. Aspectos técnicos do cultivo da abóbora na região Nordeste do Brasil. Embrapa Tabuleiros Costeiros, Documentos 154,2010

(a8) DIAS, R. C. S.; LIMA, M. A. C. Sistema de produção de melancia: Embrapa Semiárido, Sistemas de Produção 6, Ago/2010,

(a9) DANTAS, J. L. L.; JUNGHANS, D. T.; LIMA, J. F. Mamão: O produtor pergunta, a Embrapa responde. $2^{\mathrm{a}}$ ed. Brasília, DF: Embrapa Empresa Brasileira de Pesquisa Agropecuária, 2013. 176 p.

(a10) Andrade Jr. et al. Produção de maracujazeiro-amarelo sob diferentes densidades de plantio. Pesquisa Agropecuária Brasileira, v. 38, n.12, p. 1381-1386, 2003.

(b, c, d, e, f) Feedipedia: Animal feed resources information system. Available at: http://www.feedipedia.org/, access 07/2019. 

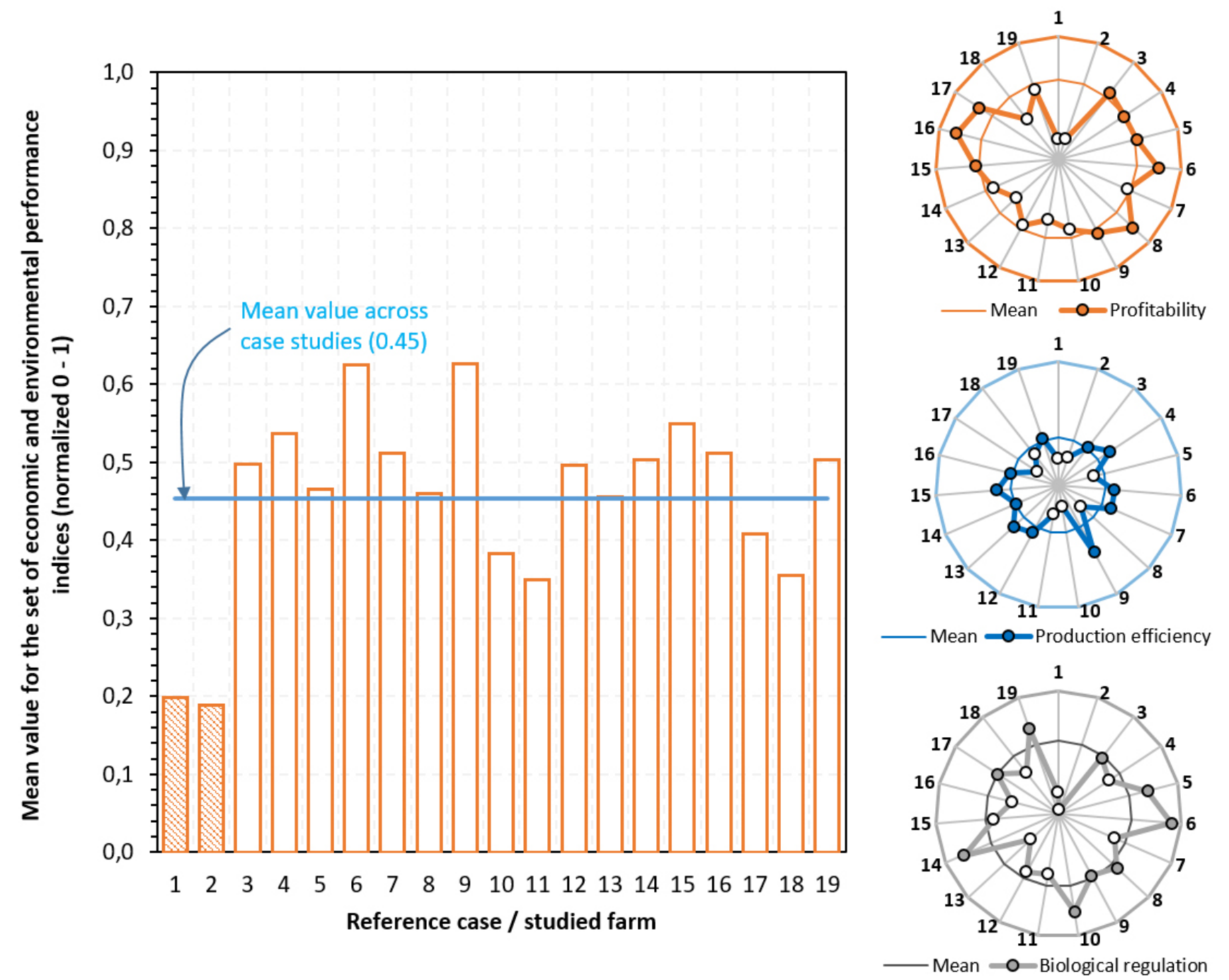

Figure 1. Mean economic-environmental performance indices for the monoculture (cases 1 and 2) and multi-species intercropping systems based on citrus in the region of the Coastal Tablelands of Sergipe and Bahia states (Northeastern Brazil).

Source: Authors 
Table 4. Individual scores of each indicator in three principles for all 19 farms (normalized $0-1$ )

\begin{tabular}{|c|c|c|c|c|c|c|c|c|c|c|c|c|}
\hline \multirow[b]{2}{*}{ 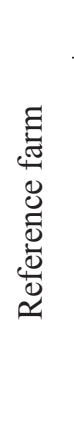 } & \multicolumn{3}{|c|}{ Profitability } & \multicolumn{7}{|c|}{ Production efficiency } & \multicolumn{2}{|c|}{ Biological regulation } \\
\hline & $\begin{array}{l}\stackrel{\Xi}{\Xi} \\
\pm \\
0 \\
0 \\
0\end{array}$ & 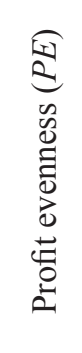 & 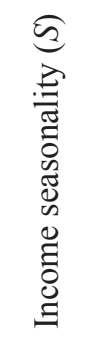 & 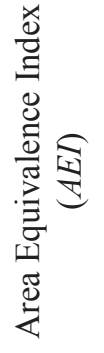 & 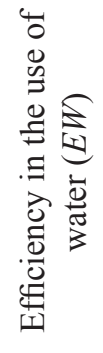 & 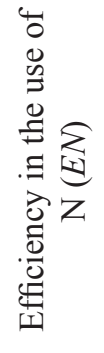 & 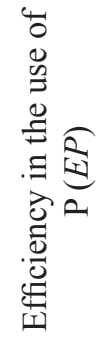 & 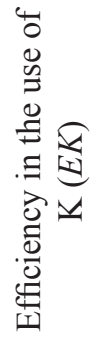 & 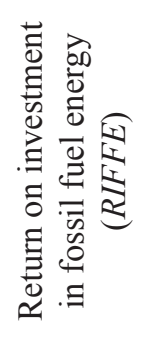 & 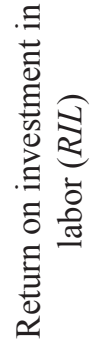 & 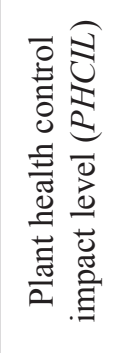 & 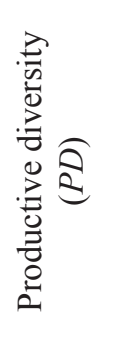 \\
\hline 1 & 0.07 & 0.00 & 0.42 & 0.16 & 0.25 & 0.41 & 0.17 & 0.07 & 0.11 & 0.37 & 0.35 & 0.00 \\
\hline 2 & 0.07 & 0.00 & 0.44 & 0.21 & 0.29 & 0.39 & 0.22 & 0.07 & 0.16 & 0.34 & 0.07 & 0.00 \\
\hline 3 & 0.71 & 0.42 & 0.93 & 1.00 & 0.57 & 0.26 & 0.21 & 0.09 & 0.28 & 0.35 & 0.36 & 0.79 \\
\hline 4 & 0.65 & 0.39 & 0.87 & 0.71 & 1.00 & 0.29 & 0.17 & 0.08 & 0.91 & 0.37 & 0.00 & 1.00 \\
\hline 5 & 0.56 & 0.91 & 0.50 & 0.41 & 0.70 & 0.00 & 0.00 & 0.00 & 0.50 & 0.50 & 0.95 & 0.54 \\
\hline 6 & 0.96 & 0.81 & 0.69 & 0.38 & 0.51 & 0.93 & 0.32 & 0.17 & 0.54 & 0.34 & 0.90 & 0.96 \\
\hline 7 & 0.69 & 0.24 & 0.91 & 0.30 & 0.52 & 0.24 & 0.46 & 0.06 & 1.00 & 0.71 & 0.33 & 0.66 \\
\hline 8 & 1.00 & 0.45 & 1.00 & 0.47 & 0.62 & 0.22 & 0.07 & 0.03 & 0.19 & 0.16 & 0.81 & 0.49 \\
\hline 9 & 0.72 & 0.80 & 0.54 & 0.51 & 0.79 & 0.33 & 1.00 & 0.12 & 0.57 & 1.00 & 0.67 & 0.47 \\
\hline 10 & 0.75 & 0.19 & 0.79 & 0.27 & 0.41 & 0.12 & 0.12 & 0.04 & 0.15 & 0.14 & 0.61 & 0.99 \\
\hline 11 & 0.68 & 0.13 & 0.68 & 0.37 & 0.28 & 0.31 & 0.19 & 0.03 & 0.31 & 0.22 & 0.18 & 0.81 \\
\hline 12 & 0.58 & 0.62 & 0.62 & 0.46 & 0.49 & 1.00 & 0.42 & 0.13 & 0.22 & 0.34 & 0.43 & 0.64 \\
\hline 13 & 0.53 & 0.57 & 0.29 & 0.32 & 0.35 & 0.14 & 0.88 & 0.21 & 0.58 & 0.98 & 0.39 & 0.22 \\
\hline 14 & 0.54 & 0.78 & 0.41 & 0.37 & 0.21 & 0.45 & 0.53 & 0.24 & 0.38 & 0.44 & 0.93 & 0.75 \\
\hline 15 & 0.60 & 0.95 & 0.48 & 0.31 & 0.35 & 0.31 & 0.75 & 1.00 & 0.33 & 0.47 & 0.30 & 0.76 \\
\hline 16 & 0.67 & 1.00 & 0.90 & 0.24 & 0.70 & 0.61 & 0.50 & 0.10 & 0.41 & 0.25 & 0.34 & 0.43 \\
\hline 17 & 0.83 & 0.64 & 0.84 & 0.41 & 0.36 & 0.15 & 0.10 & 0.01 & 0.20 & 0.18 & 0.63 & 0.56 \\
\hline 18 & 0.49 & 0.55 & 0.18 & 0.24 & 0.17 & 0.23 & 0.80 & 0.11 & 0.22 & 0.42 & 0.33 & 0.51 \\
\hline 19 & 0.70 & 0.54 & 0.54 & 0.27 & 0.54 & 0.34 & 0.64 & 0.11 & 0.54 & 0.38 & 0.76 & 0.70 \\
\hline Mean & 0.62 & 0.53 & 0.63 & 0.39 & 0.48 & 0.35 & 0.40 & 0.14 & 0.40 & 0.42 & 0.49 & 0.59 \\
\hline
\end{tabular}

Source: Authors.

It can be observed that establishments dedicated to citrus monoculture presented significantly lower integrated economic-environmental performance indices (around 0.20), according to the mean values for the full set of 12 indicators. All the fruit farms with citrus intercropping showed higher performance indices, ranging from 0.35 to 0.63 with an average of 0.50 . Seven rural establishments that developed citrus intercropping (37\%) showed performance values above this average, especially among establishments that used citrus intercropped with corn, cowpea and cassava (producer 6) and cultivation of citrus intercropped with pumpkin and corn (producer 9), both with an environmental-economic performance index of 0.63 . The higher performance indices were observed, almost exclusively, in the establishments that intercropped more than one crop into the citrus orchards, and these crops included cassava, maize, or both.
The main contrasts for determining this performance ranking were observed in the indicators of Profitability (mean $=0.59)$, followed by Production efficiency (mean $=0.53$ ) and Biological regulation (mean $=0.37$ ). The 'heat map' presented in Figure 2 shows that citrus monocultures performed lowest in all three principles, while all intercropping systems showed values at least equal to the mean, in at least one of these principles. 


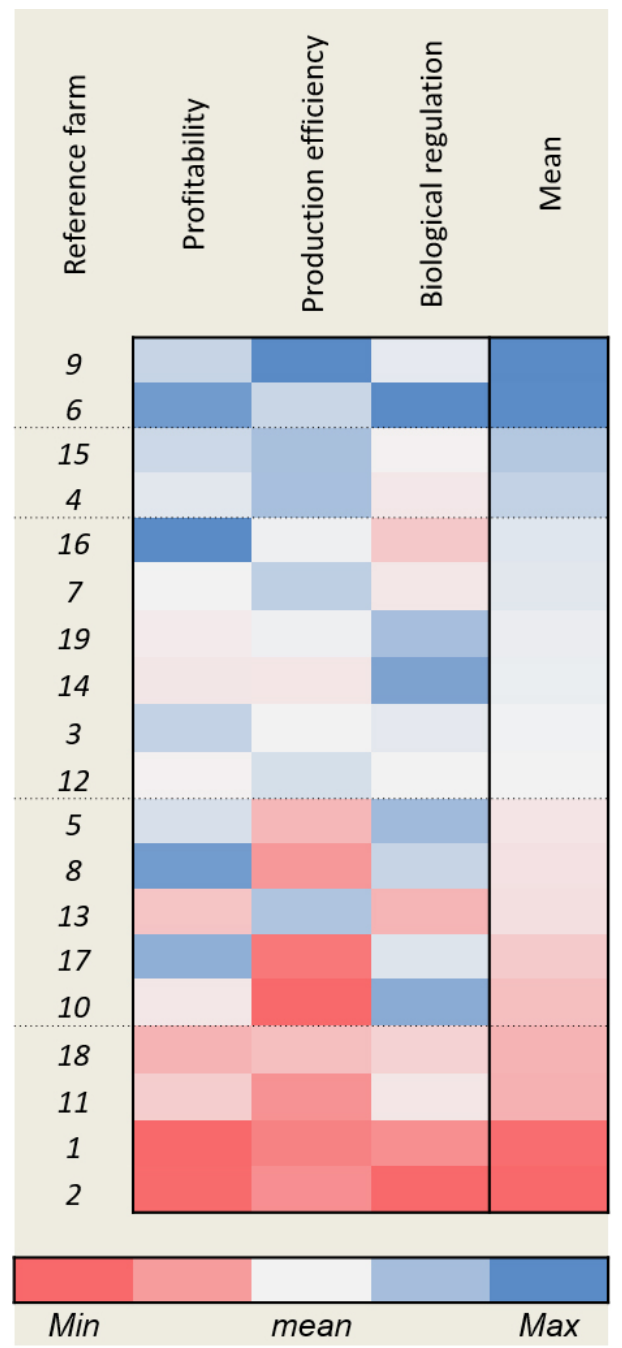

Figure 2. 'Heat map' displaying the performance ranking of 19 citrus production farms, either in monoculture (1 and 2) or multispecies intercropping (3-19), according to 12 economic-environmental indicators, assessed in the Coastal Tablelands region of Northeastern Brazil.

Source: Authors

Five clusters can be highlighted in the heatmap:

- Cluster 1: Farms 2 and 1, citrus monocultures showing worse performance in all three principles; and 11 and 18 with poor performance in the three principles;

- Cluster 2: Farms 10, 17, 13, 8, 5, above average performance in at least 1 principle;

- Cluster 3: Farms 12, 3, 14, 19, 7, 16, close to average performance for all 3 principles;

- Cluster 4: Farms 4, 15, above average in at least 2 principles (profitability and production efficiency);

- Cluster 5: Farms 6, 9, high performance indices in all three principles.

The indices presenting the best mean performances across all case studies were seasonality $(0.63)$, profit $(0.62)$ and productive diversity $(0.59)$, followed by profit evenness (0.53), plant health control impact level (0.49), efficiency in the use of water $(0.44)$ and phosphate $(0.42)$, return on investment in labor (0.42) and in fossil energy (0.40), area equivalence index (0.39), efficiency in the use of nitrogen (0.37) and potassium (0.15) (Figure 3).
The best performance indices were observed, almost exclusively, in the establishments that intercropped more than one crop into the citrus orchards, and cassava or maize were one of these crops. Of the rural establishments with performance indices lower than the average, there are those that cultivated okra, common beans, pumpkin, papaya, and passion fruit. However, even being lower than average, the results demonstrate that the economicenvironmental performances of these intercropped systems were superior, as compared to citrus monocultures. It is important to point out that both establishments with citrus monoculture scored lower (index $=0.19$ ) than those with the lowest economic-environmental performances for multi-species intercropping. 


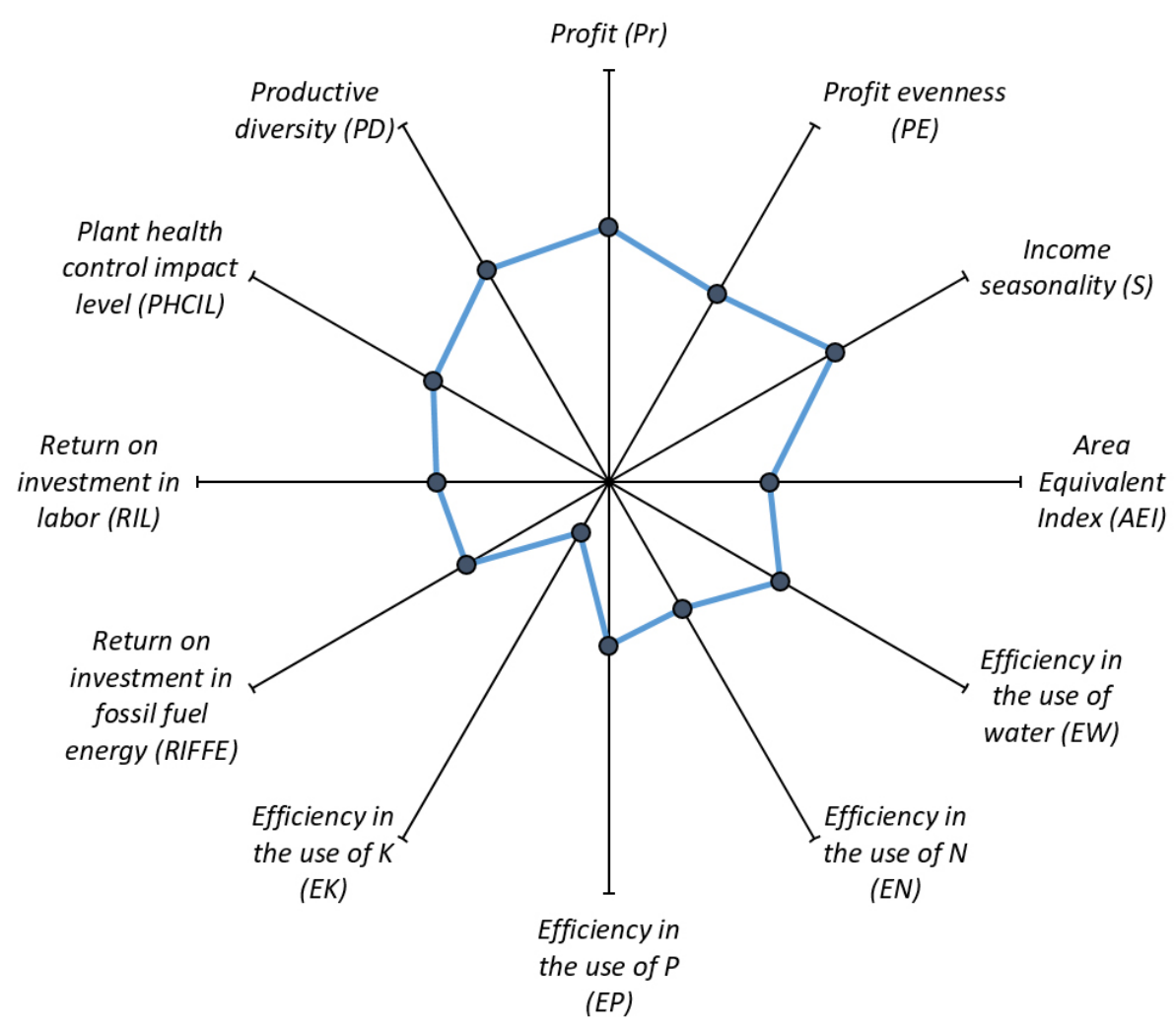

Figure 3: Mean values for the indicator performance indices across the 19 case studies of monoculture and multispecies intercropping systems based on citrus in the region of the Coastal Tablelands of Sergipe and Bahia states (Brazil).

Source: Authors

Regarding the principle of profitability, citrus monoculture establishments (1 and 2) presented the lowest profit and profit evenness indices. The profit of citrus multi-species intercropping resulted in indices ranging from 0.49 to 1.0 with a 0.69 average. The establishments above this average were those in which citrus was intercropped with papaya and watermelon (farm 3); citrus with maize, cowpea and cassava (farm 6); citrus with pumpkin and maize (farm 9); citrus with okra and yam (farm 10); citrus with okra and pumpkin (farm 17) and citrus with passion fruit and corn (farm 19). It is worth highlighting the establishment with the citrus intercropped with cassava, which presented the maximum profit index (farmer 8).

The profit evenness indices for the intercropped areas ranged from 0.13 to 1.0 with an average of 0.59 . The establishments with multi-species intercropping with above-average profit evenness were citrus with cassava (farm 5); citrus with maize, cowpea and cassava (farm 6); citrus with pumpkin and maize (farm 9); citrus with cowpea and pumpkin (farm 12); citrus with peanuts (farm 14); citrus with corn and cassava (farm 15); citrus with okra and pumpkin (farm 17). The best performer for this indicator was the establishment with citrus intercropped with passion fruit (farm 16).
Regarding the seasonality indicator, except for establishments with citrus monoculture, the indices ranged from 0.18 to 1.0 with a 0.66 average. Poorer performances were observed in citrus intercropping with maize, with a 0.29 score (farm 13), citrus with beans with a 0.18 index (farm 18), and citrus with peanuts with a 0.41 index (farm 14). The best performance for this indicator occurred again in the citrus with cassava intercrop, which presented the maximum score for the profit indicator (farmer 8). It should be emphasized that corn, beans, and peanuts are short-cycle crops (3 to 4 months) with prompt commercialization, that is, very seasonal. Cassava, on the other hand, is usually harvested over a long period, up to two years, according to the farmers' needs. 
With respect to the productive efficiency principle, as expected, establishments with citrus monoculture showed the lowest area equivalence index performances. By contrast, in the other indicators such as water, N, P and $\mathrm{K}$ use efficiencies, as well as return on investment in fossil energy and in labor, mono-crop performance results remained close to or even higher than some of the multi-species intercrops. The area equivalence index for intercropping ranged from 0.21 to 1.0 with an average of 0.41 . The establishments above this average were those with citrus intercrop with cassava, papaya and peanut (farm 4), citrus with cassava (farm 8), citrus with pumpkin and maize (farm 9), and citrus with cowpea and pumpkin (farm 12). Citrus intercropped with papaya and maize resulted in the best area equivalence index (farm 3 ) among the evaluated systems.

Regarding the water efficiency indicator $(\mathrm{kg}$ produce $/ \mathrm{m}^{3}$ ), citrus monoculture systems scored 0.25 and 0.29 , values higher than establishments with citrus intercropped with peanut (farm 14) and citrus with okra and pumpkin (farm 17). The water use efficiency indices ranged from 0.17 to 1.0 with an average of 0.50 . There were nine establishments with performances above this value, i.e., citrus intercropped with papaya and watermelon (farm 3), citrus with cassava (farm 5), citrus with corn, cowpea and cassava (farm 6), citrus with fava and citrus with passion fruit and maize (farm 9), citrus with passion fruit (farm 16) and citrus with passion fruit and maize (farm 19). The best performance in water use efficiency among the citrus intercropping systems was the combination with cassava, papaya, and peanut (farm 4).

The efficiency in the use of $\mathrm{N}$ indices ranged from 0.14 to 1.0 with an average of 0.37 . It is worth mentioning that the indicator of efficient use of nitrogen for citrus monocultures was superior to over $75 \%$ of the multispecies intercropping systems, being surpassed only by the establishments that cultivated citrus intercropped with maize (farm 6), with cowpea and cassava (farm 12), with cowpea and pumpkin (farm 14) and citrus intercropped with passion fruit (farm 16). In general, the efficiency in which nutrients applied are transformed into plant biomass depends on complex processes involving plant, environment, and fertilizer technology. There are also losses during crop development, that can reach more than $90 \%$ of the $\mathrm{N}$ applied, depending on cultural practices, soil and water (OLIVEIRA et al., 2015), and intercropping is considered a way to reduce $\mathrm{N}$ losses substantially (MANEVSKI et al., 2015).
The efficiency in the use of $\mathrm{P}$ indices ranged from 0.10 to 1.0 with an average of 0.45 . Based on this indicator, eight multi-species combinations presented above-average indices, with the citrus with pumpkin and maize (farm 9) being the most efficient. Regarding the efficiency of the use of $\mathrm{K}$, indices ranged from 0.10 to 1.0 with a mean of 0.16 . Only four intercropping establishments had aboveaverage rates, especially the citrus with cassava and maize (farm 15). Potassium fertilization employed in these four consortia averaged $19.3 \mathrm{~kg} \cdot \mathrm{ha}^{-1}$, while in the others the average was close to $96 \mathrm{~kg}$.ha ${ }^{-1}$, i.e., a volume 3 to 4 -fold those observed in the most efficient $\mathrm{K}$ applications. The water content in the soil affects the contact of potassium with the roots, as well as its absorption. Generally, the absorption of potassium occurs by diffusion, however, in low extra-cellular concentrations, the absorption of potassium depends on energy (ATP) investment (TAIZ; ZEIGER, 2013). Thus, the moisture content in the soils is determinant in the rate of absorption of potassium by the plants.

The analysis of return on investment in fossil energy used in production showed that citrus monoculture performances were lower than intercropped systems, with indices ranging from 0.15 to 1.0 with average of 0.43 . Among these, only seven intercropping areas had above-average indices, with citrus intercropped with cassava, papaya, and peanuts (farm 4) scoring 0.9 and citrus with pumpkin and maize (farm 9) scoring 1.0. As for the return on investment in labor, indices ranged from 0.14 to 1.0 with a mean of 0.43 . In this indicator only six establishments showed performances above average values, including citrus intercropping with maize (farm 13) and citrus with pumpkin and maize (farm 9), with indices of 0.98 and 1.0, respectively.

Regarding the principle of biological regulation, the indicator of plant health control impact level ranged from zero to 0.95 with a mean of 0.53 . Eight aboveaverage establishments were found, with highlight for three intercropping systems with indices close to 1.0, i.e., 0.95 for the citrus with cassava (farm 5), 0.90 for citrus intercropping with maize, cowpea and cassava (farm 6) and 0.93 for the citrus with peanuts (farm 14).

As for the indicator of productive diversity, in the intercropping systems indices ranged from 0.22 to 1.0 with an average of 0.66 . In this indicator nine establishments resulted in above-average indices, with citrus intercropped with maize, cowpea, and cassava scoring 0.96 (farm 6), citrus with okra and yam scoring 0.99 (farm 10), and the citrus with cassava, papaya, and peanut scoring 1.0 (farm 4). 
Once all the principles and indicators have been considered, as to their general distributions along the gradient of citrus monoculture and intercropping systems, a question remains regarding their possible correlations, as well as about the plant combinations that may better explain the observed economic-environmental performances. In order to explore these aspects, a Principal Components Analysis (PCA) was carried out, combining the information on the five clusters derived from the general mean performances for the three principles (as shown in the heat map of Figure 2) and the 19 cropping systems studied. The PCA shows that there is a positive and significant correlation $(\mathrm{R}=0.6724)$ between the principles Profitability and Biological regulation, and that both principles are associated with the F1 axis that accounts for $\sim 60 \%$ of the variation. The Production efficiency principle does not correlate with the other two principles and is associated with the $\mathrm{F} 2$ axis, which accounts for $\sim 30 \%$ of the variation (Figure 4 ).
Regarding the crop combinations, it is not possible to identify any clear pattern of plant associations and performance in the considered principles, except that citrus intercropping presented better performance than monocultures, in the three principles considered. Most likely, the main performance differences between crop combinations were due to the diversity of orchard management strategies, as depicted by the set of indicators, rather than the specific crop combination, considering the universe of species observed in the study.

\section{Biplot (axes F1 e F2: $90.40 \%$ )}

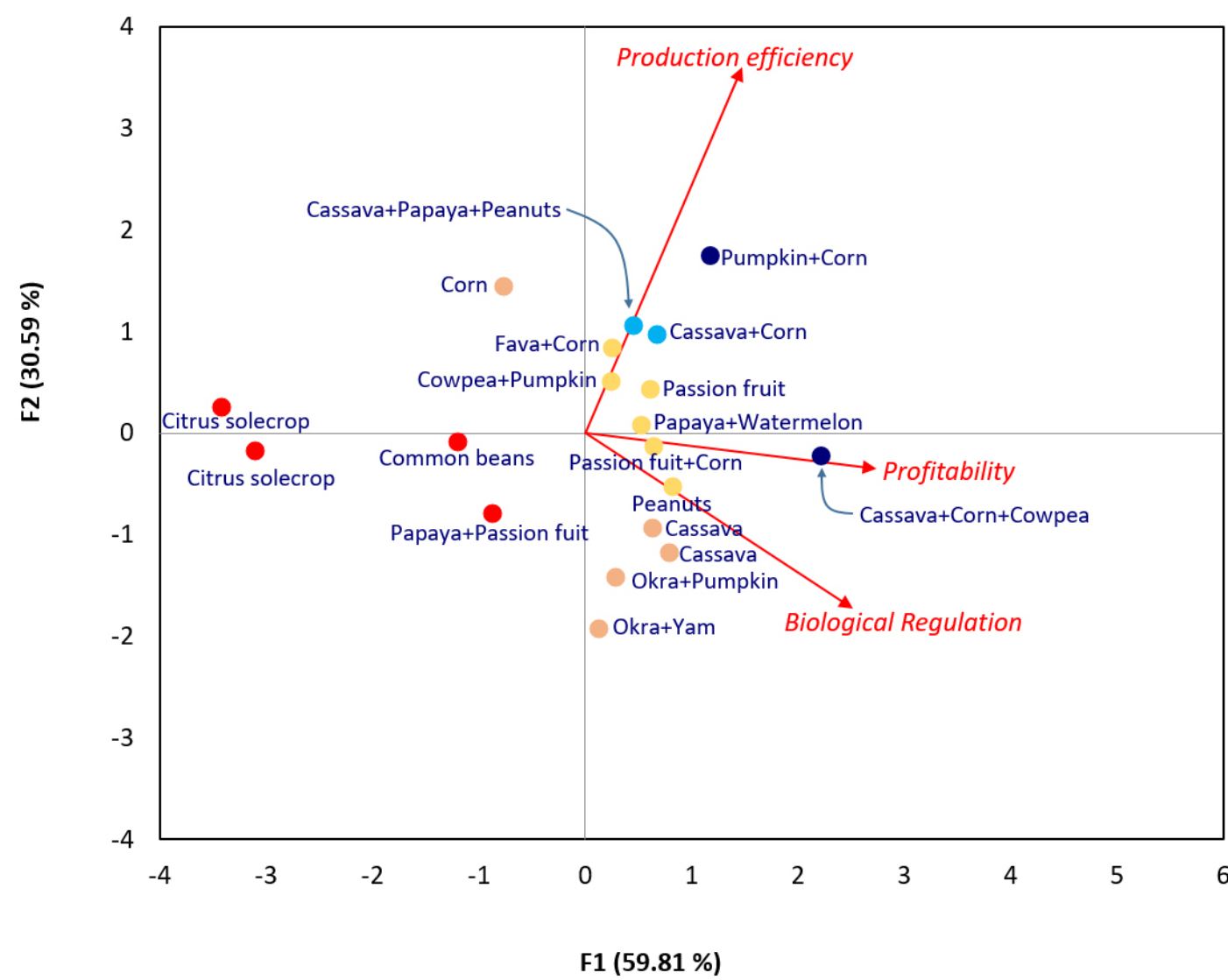

Figure 4. Biplot of the Principal Component Analysis for citrus-based intercropping systems correlating different combinations of plant species and the performance indices for three economic-environmental principles: Profitability, Productive efficiency, and Biological regulation.

Source: Authors 


\section{Conclusions}

The economic and environmental performances of citrus monoculture resulted inferior to the multispecies intercropped systems in the Coastal Tablelands region. Citrus intercropping with cassava, corn, common bean, cowpea, yam, fava, pumpkin, okra, peanut, watermelon, papaya, and passion fruit bring economic and environmental benefits to the fruit producing farms.

Cultures intercropped with citrus that promoted the best environmental economic performance indices were cassava; cassava, corn, and beans; corn and pumpkin. The indicators associated with these economic-environmental performances were as follows, in decreasing importance order: (1) profit, (2) seasonality, (3) productive diversity, (4) profit evenness, (5) plant health control impact level, (6) efficiency in the use of water and (7) phosphate, (8) return on investment in labor and in (9) fossil energy, (10) area equivalence index, (11) efficiency in the use of nitrogen and (12) potassium.

\section{Acknowledgements}

We are thankful to all farmers and agricultural extensionists of EMDAGRO-SE who lent their time, knowledge, and experience in favor of this study. This research was funded by the Brazilian Agricultural Research Corporation (Embrapa). Project MP2 Nr. 02.12.01.013.00.00.

\section{References}

ABREU, Â. de F.B.; BIAVA, M. Cultivo do feijão da primeira e segunda safras na Região Sul de Minas Gerais. Santo Antônio de Goiás: Embrapa Arroz e Feijão; Campinas: Embrapa Informática Agropecuária, 2005. (Sistemas de produção, 6).

ANDO-MENSAH, E.; OFOSU-BUDU, G.K. Evaluation of coconut-citrus intercropping systems in the context of lethal yellowing disease of coconut in Ghana. African Journal Food, Agriculture, Nutrition and Development, Nairobi, v.12, n.7, p.6945-6962, 2012.

ANDRADE JUNIOR, V.C.A.; ARAÚJO NETO, S.E.; RUFINI, J.C.M.; RAMOS, J.D. Produção de maracujazeiro-amarelo sob diferentes densidades de plantio. Pesquisa Agropecuária Brasileira, Brasília, DF, v.8, n.12, p.1381-1386, 2003.
ANDREOLI, M.; TELLARINI, V.Farm sustainability evaluation: methodology and practice. Agriculture, Ecosystems \& Environment, Amsterdam, v.77, n.1-2, p.43-52, 2000.

AZEVEDO, C.L.L.; PASSOS, O.S.; SANTANA, M.A. Sistema de produção para pequenos produtores de citros do Nordeste. Cruz das Almas: Embrapa Mandioca e Fruticultura, 2006. 55p.(Documentos, 157).

BARROS, I.; MARTINS, C.R.; RODRIGUES, G.S.; TEODORO, A.V. Intensificação ecológica da agricultura. Aracaju: Embrapa Tabuleiros Costeiros, 2016. 31p. (Documentos, 208).

BELLOTTE, J.A.M.; KUPPER, K.C.; RINALDO, D.; SOUZA, A. de; GOES, A. The effects of inter-crop cultivation between rows of citrus crop on spreading of Guignardia citricarpa ascospores and in the citrus black spot occurrence. Revista Brasileira de Fruticultura, Jaboticabal, v.35, n.1, p.102-111, 2013.

BOCKSTALLER, C.; GIRARDIN, P.; VAN DER WERF, H.M.G. Use of agro-ecological indicators for the evaluation of farming systems. Reprinted from the European Journal of Agronomy, Amsterdam, v.7, n.1-3, p.261-270, 1997.

BOSSHARD, A. A methodology and terminology of sustainability assessment and its perspectives for rural planning. Agriculture, Ecosystems \& Environment, Amsterdam, v.77, n.1-2, p.29-41, 2000.

CARVALHO, H.W.L. de; TEODORO, A.V.; BARROS, I.; CARVALHO, L.M. de; SOARES FILHO, W.S.; GIRARDI, E.A.; PASSOS, O.S.; PINTO-ZEVALLOS, D.M. Rootstock-related improved performance of 'Pera' sweet orange under rainfed conditions of Northeast Brazil. Scientia Horticulturae, Wageningen, v.263, p.109-148, 2020.

CARVALHO, L.M. de; CARVALHO, H.W.L.de; BARROS, I.; MARTINS, C.R.; SOARES FILHO, W.S.; GIRARDI, E.A.; PASSOS.O.S. New scion-rootstock combinations for diversification of sweet orange orchards in tropical hardsetting soils. Scientia Horticulturae, Wageningen, v.243, p.169-176, 2019.

COELHO, G.C. Ecosystem services in Brazilian's southern agroforestry systems. Tropical and Subtropical Agroecosystems, Yucatán, v.20, n.3, p.475-492, 2017. 
CURTOLO, M.; CRISTOFANI-YALY, M.; GAZAFFI, R.; TAKITA, M.A.; FIGUEIRA, A.; MACHADO, M.A. QTL mapping for fruit quality in Citrus using DArTseq markers. BMC Genomics, Londres, v.18, n.1, p.289, 2017.

CRUZ, J.C.; KARAM, D.; MONTEIRO, M.A.R.; MAGAlHÃES, P.C. (ed.). A cultura do milho. Sete Lagoas: Embrapa milho e sorgo, 2010. Disponível em: http://www.cnpms.embrapa.br/publicacoes/milho6ed/ index.htm. Acesso em: 7 maio 2017.

DAI, J.; QIU, W.; WANG, N.; WANG, T.; NAKANISHI, H.; ZUO, Y. From leguminosae/gramineae intercropping systems to see benefits of intercropping on iron nutrition. Frontiers in Plant Science, Parkville, v.10, p.605, 2019.

DAI, X.; PU, L.; RAO, F. Assessing the Effect of a CropTree Intercropping program on Smallholders' incomes in rural Xinjiang, China. Sustainability, Basiléia, v.9, n.9, p. $1542,2017$.

DANTAS, J.L.L.; JUNGHANS, D.T.; LIMA, J.F. Mamão: o produtor pergunta, a Embrapa responde. 2.ed. Brasília, DF: Embrapa, 2013. 176 p.

DIAS, R.C.S.; LIMA, M.A.C. Sistema de produção de melancia: colheita e pós colheita. Brasília (DF): Embrapa, 2010. Disponível em: https://sistemasdeproducao. embrapa.br/Fontes/Melancia/SistemaProducaoMelancia/ htm. Acesso em: nov. 2014.

DURU, M.; THEROND O.; MARTIN, G. How to implement biodiversity-based agriculture to enhance ecosystem services: A review. Agronomy for Sustainable Development, Paris, v.35, n.4, p.1259-1281, 2015.

FEEDIPEDIA: Animal feed resources information system. INRA/CIRAD/AF/FAO, 2019. Disponível em: http://www.feedipedia.org/.Acesso em: 07 Jul. 2019.

GABA, S.; LESCOURRET, F.; BOUDSOCQ, S.; ENJALBERT, J.; HINSINGER, P.; JOURNET, E.P.; NAVAS, M.L.; WERY, J.; LOUARN, G.; MALÉZIEUX, E.; PELZER, E.; PRUDENT, M.; OZIER-LAFONTAINE, H. Multiple cropping systems as drivers for providing multiple ecosystem services: From concepts to design. Agronomy for Sustainable Development, Paris, v.35, n.2, p.607-623, 2015.

GILL, M.S.; KHEHRA, S.; GUPTA, N. Impact of intercropping on yield, fruit quality and economics of young Kinnow mandarin plants. Journal of Applied and Natural Science, New Delhi, v.10, n.3, p.954-957, 2018.
GIRARDIN, P.; BOCKSTALLER, C.; VAN DER WERF, H.M.G. Indicators: tools to evaluate the environmental impacts of farming systems. Journal of Sustainable Agriculture, Binghamton, v.13, n.4, p.5-21, 1999.

GOMES, J.B.V.; ARAÚJO FILHO, J.C.; VIDALTORRADO, P.; COOPER, M.; SILVA, E.A.DA; CURI, N. Cemented Horizons and Hardpans in the Coastal Tablelands of Northeastern Brazil. Revista Brasileira de Ciência do Solo, Viçosa, MG, v.41, p.e0150453, 2017.

GRIFFON, M. Qu'est-ce que l'agriculture écologiquement intensive? Versailles: Editions Quae, 2013. 221p. (Collecton Matière à débattre \& décider)

HARDI, P.; DESOUZA-HULETEY, J.A. Issues in analyzing data and indicators for sustainable development. Ecological Modelling, Amsterdam, v.130, n.1-3, p.59-65, 2000 .

HARRISON, S.; HARRISON, R. Priority tree species and potential agroforestry species mixtures for Fiji and Vanuatu. In: HARRISON, S.; KARIM, M.S. Promoting sustainable agriculture and agroforestry to replace unproductive land use in Fiji and Vanuatu. Camberra: Australian Centre for International Agricultural Research (ACIAR), 2016. 201p.

IBGE - Instituto Brasileiro de Geografia e Estatística. SIDRA banco de tabelas estatísticas. Rio Grande do Sul: IBGE, 2018. Disponível em: htttp:www.sidra.ibge. gov.br/bda/pesquisa. Acesso em: 10 Jun. 2020.

KLEIJN, D.; BOMMARCO, R.; FIJEN, T.P.M.; GARIBALDI, L.A.; POTTS, S.G.; VAN DER PUTTEN, W.H. Ecological Intensification: bridging the gap between science and practice. Trends in Ecology \& Evolution, Cambridge, v.34, n.2, p.154-166, 2019.

L E WA N D OW S K I, I. ; HAR DT L E IN, M .; KALTSCHMITT, M. Sustainable crop production: definition and methodological approach for assessing and implementing sustainability. Crop Science, Madison, v.39, n.1, p.184-193, 1999.

LINARES, J.; SCHOLBERG, J.; BOOTE, K.; CHASE, C.A; FERGUSON, J.J.; MCSORLEY, R. Use of the cover crop weed index to evaluate weed suppression by cover crops in organic citrus orchards. HortScience, College Park, v.43, n.1, p.27-34, 2008. 
MANEVSKI, K.; BORGENSEN, C.D.; ANDERSEN, M.N., KRISTENSEN, I.S. Reduced nitrogen leaching by intercropping maize with red fescue on sandy soils in North Europe: a combined field and modeling study. Plant and Soil, Dordrecht, v.388, n.1-2, p.67-85, 2015.

MARTINELLI, R.; MONQUERO, P.; FONTANETTI, A.; CONCEIÇÃO, P.; AZEVEDO, F. Ecological mowing: an option for sustainable weed management in young citrus orchards. Weed Technology, Cambridge, v.31, n.2, p.260-268, 2017.

MARTINS, C.R.; CARVALHO, H.W.L. de; TEODORO, A.V.; BARROS, I.; CARVALHO, L.M. de; SOARES FILHO, W. dos S.; PASSOS, O.S. Performance of the pineapple sweet orange on different rootstocks. Bioscience Journal, Uberlandia, v.36, n.2, p.458-472, 2020.

MARTINS, C.R.; CARVALHO, H.W.L.; TEODORO, A.V.; SOARES FILHO, W.S.; PASSOS, O.S. Agronomical performance of citrus scion cultivars grafted on Rangpur lime in north-eastern Brazil. Australian Journal of Crop Science, Lismore, v.10, n.1, p.16-23, 2016.

MELO FILHO, J.F.; CARVALHO, L.L.; SILVEIRA, D.C.; SACRAMENTO, J.A.A.S.; SILVEIRA, E.C.P. Quality index in a cohesive yellow latosol cultivated with citrus. Revista Brasileira de Fruticultura, Jaboticabal, v.31, n.4, p.1168-1177, 2009.

MENESES, T.N.; COELHO FILHO, M.A.; SANTOS FILHO, H.P.; SANTOS, L.L.A.; GESTEIRS, A.S.; SOARES FILHO, W.S.S.; PASSOS, O.S. Subsoiling and planting method on the initial growth of 'pera' sweet orange (Citrus sinensis (L.) Osbeck). Journal of Agricultural Science, Richmond Hill, v.11, n.9, p.1-10, 2019.

MULINGE, J.M.; SAHA, H.M.; MOUNDE, L.Ç.; WASILWA, L.A. Effects of legume cover crops on orange (Citrus sinensis) fruit weight and brix. International Journal of Plant \& Soil Science, Hooghly, v.21, n.4, p.1-9, 2018.

MVONDO, A.E.; NDO, E.G.D., NGO BIENG, M.A.; ZACHÉE, A.; MANGA, B.; CILAS, C.; MANGA, M.L.T.; NOMO, L.B. Assessment of the interaction between the spatial organization of citrus trees populations in cocoa agroforests and Phytophthora foot rot disease of citrus severity. Agroforestry Systems, Berlim, v.93, n.2, p.493-502, 2019.
NEVES, M.F.; TROMBIN, V.G.; LOPES, F.F.; KALAKI, R.; MILAN, P. Brazil's citrus belt (São Paulo and Triângulo Mineiro). In: NEVES, M.F; TROMBIN, V.G.; LOPES, F.F.; KALAKI, R.; MILAN, P.(ed.). The orange juice business. Wageningen: Academic Publishers, 2011.176 p.

OLIVEIRA, P.N. de; DOVIS, V.L.; MATTOS JUNIOR, D. de. Nitrogênio na cultura dos citros. Piracicaba: IPNI, 2015.p.6-14. (Informações Agronômicas, 163).

OUMA, G.; JERUTO, P. Sustainable horticultural crop production through intercropping: the case of fruits and vegetable crops: A review. Agriculture and Biology Journal of North America, Colorado, v.1, n.5, p.1098$1105,2010$.

PAULUS, D.; BECKER, D.; NAVA, G.A.; LUCKMANN, D.; MOURA, C. de A. Cultivation of mint (Mentha $\mathrm{x}$ gracilis) in intercropping with fruit trees in an agroforestry system: production and quality of essential oil. European Journal of Medicinal Plants, Exeter, v.30, n.1, p.1-9, 2019.

PAUT, R.; SABATIER, R.; TCHAMITCHIAN, M. Modelling crop diversification and association effects in agricultural systems. Agriculture, Ecosystems \& Environment, Amsterdam, v.288, p.106711, 2020.

PRETTY, J. Intensification for redesigned and sustainable agricultural systems. Science, Washington, v.362, n.6417, eaav0294, 2018.

RAMOS, S.S.R.; LIMA, N.R.S.; CARVALHO, H.W.L.; OLIVEIRA, I.R.; SOBRAL, F.S.; CURADO, F.F. Aspectos técnicos do cultivo da abóbora na região Nordeste do Brasil. Aracaju: Embrapa Tabuleiros Costeiros, 2010. 36p. (Documentos, 154).

RIBEIRO, V.Q. Cultivo do feijão-caupi (Vigna unguiculata (L.) Walp.). Teresina: Embrapa Meio-Norte, 2002. 108p. (Sistemas de Produção, 2)

RODRIGUES, G.S.; BARROS, I.; EHABE, E.E.; SAMA LANG, E.; ENJALRICK, F. Integrated indicators for performance assessment of traditional agroforestry systems in South West Cameroon. Agroforestry Systems, Berlim, v.77, n.1, p.9-22, 2009.

RODRIGUES, G.S.; RODRIGUES, I.A.; BUSCHINELLI, C.C. de A.; BARROS, I. Integrated farm sustainability assessment for the environmental management of rural activities. Environmental Impact Assessment Review, Berlim, v.30, n.4, p.229-239, 2010. 
RODRIGUES, M.J.D.S.; OLIVEIRA, E.R.M.D.; GIRARDI, E.A.; LEDO, C.A.D.S.; SOARES FILHO, W.D.S. Citrus nursery tree production using different scion and rootstock combinations in screen house. Revista Brasileira de Fruticultura, Jaboticabal, v.38, n.1, p.187201, 2016.

ROSA-SCHLEICH, J.; LOOS, J.; MUßHOFF, O.; TSCHARNTKE, T. Ecological-economic trade-offs of Diversified Farming Systems - A review. Ecological Economics, Amsterdam, v.160, p.251-263, 2019.

SANTANA, L.G.L.; SOUZA, E.S.; LEDO, C.A.S.; PASSOS, O.S.; COELHO FILHO, M.A.; GESTEIRA, A.S.; SOARES FILHO, W.S. Reaction to drought stress of citrus progenies with potential use for rootstocks development. Brazilian Journal of Botany, São Paulo, v.42, n.4, p.591-599, 2019.

SELIM, M.; HEFNY, Y.; ABDEL-WAHAB, E.; MOHAMED, M. Interplanting some soybean cultivars with mandarin trees in sandy soil. Agricultural Sciences, Wuhan, v.11, n.1, p.88-110, 2020.

SINGH, S.K.; SINGH, S.K.; SINGH, S. Vegetable crops as most efficient and economical intercrops: a brief review. Plant Archives, Punjab, v.18, n.1, p.923-929, 2018.

SINGHA, S.; UDDIN, M.S.; BANIK, S.; KASEM, M.A. Homestead agroforestry systems practiced at Kamalganj Upazila of Moulvibazar District in Bangladesh. Asian Journal of Research in Agriculture and Forestry, v.2, n.2, p.1-8, 2018.
TAIZ, L.; ZEIGER, E. Fisiologia vegetal. 5.ed. Porto Alegre: Artemed, 2013. 954 p.

TEODORO, A.V.; CARVALHO, H.W.L. de, BARROS, I.; CARVALHO, L.M. de; MARTINS, C.R.; SOARES FILHO, W.S.; GIRARDI, EDUARDO A.; PASSOS, ORLANDO, S. Performance of 'Jaffa' sweet orange on different rootstocks for orchards in the Brazilian Northeast. Pesquisa Agropecuária Brasileira, Brasília, DF, v.55, p.e01665, 2020.

USDA - United States Department of Agriculture. Foreign Agricultural Service. Orange juice: supply and distribution in selected countries. 2020. Disponível em: https://apps.fas.usda.gov/psdonline/ reporthandler.ashx? reportId $=2181 \&$ template Id $=8 \&$ format $=$ html $\&$ fileName $=$ Orange $\% 20$ Juice $\% 20$ Production, \%20Supply\%20and\%20Distribution $\% 20$ in\%20Selected\%20Countries. Acesso em: 04 Jun. 2020.

VIDAL, C.R.M. Absorção de NPK na cultura do inhame (Dioscorea cayennensis Lam) em três densidades de plantio. 2008. Dissertação (Mestrado em Ciências Agrárias) - Universidade Federal do Recôncavo da Bahia, Cruz das Almas, 2008.

WICHMANN, W. World fertilizer use manual. Paris: IFA, 1992. 663p. 